\title{
Il disegno riscopre la sua intrinseca resilienza multidisciplinare
}

Francesca Maria Ugliotti

Anna Osello

Abstract

Multidisciplinarietà, interoperabilità e resilienza sono le sfide che il settore disciplinare del disegno deve affrontare nel contesto della quarta rivoluzione industriale. La vera innovazione è insita nella definizione di procedure e strumenti di rappresentazione digitale che supportino l'interpretazione di informazioni connotate da crescente complessità. L'inesauribile linguaggio espressivo del disegno acquista rinnovato vigore dal paradigma del Digital Twin nella ricerca di forme di rappresentazione sempre più performanti del patrimonio costruito. E importante che questo impulso si affermi con forza anche nei percorsi universitari per formare ingegneri e architetti capaci di confrontarsi con le mutevoli esigenze del mondo moderno. L'articolo illustra un approccio didattico innovativo, sviluppato a partire da una precedente attività di ricerca, che riconosce nel disegno la capacità trasversale di connessione tra saperi, tecniche e strumenti.

Parole chiave

disegno, interdisciplinarietà, interoperabilità, didattica, Digital Twin.

Approccio didattico innovativo multidisciplinare (immagini elaborate da due gruppi di studenti del corso).
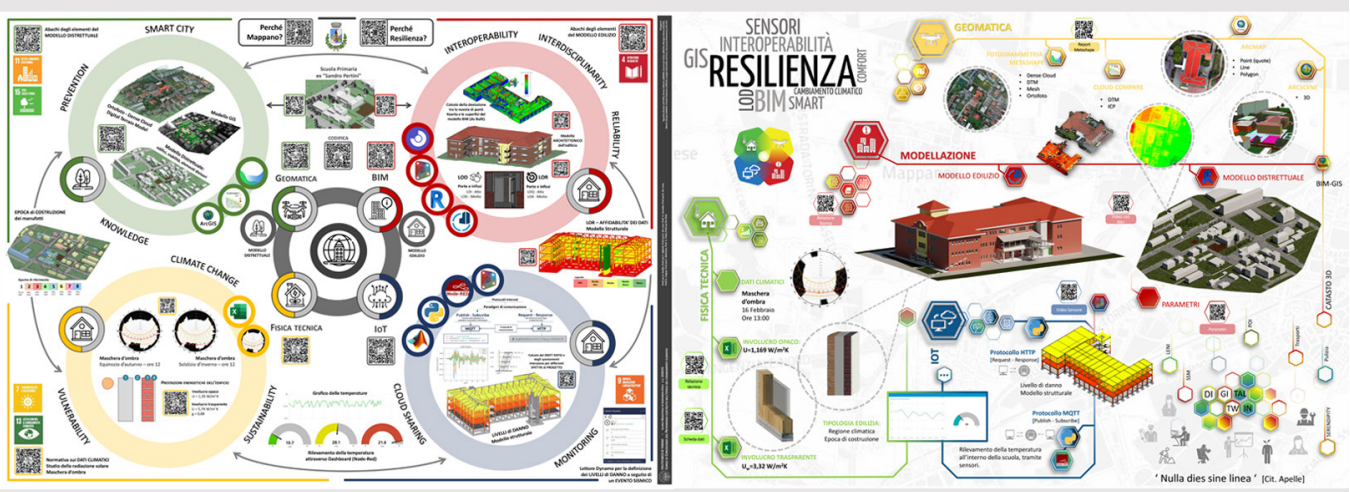


\section{Introduzione}

Resilienza e adattamento ai cambiamenti climatici sono i temi al centro di interesse a cui nei prossimi anni si dovranno dare risposte sempre più concrete e attuabili. In questo scenario la città e gli edifici assumono un ruolo cardine per cui risulta necessario attivare processi di ripensamento complessivo delle realtà in cui viviamo, della modalità di analizzarle e di rappresentarle. II periodo pandemico in corso ha sottolineato quanto la capacità di adattamento a contesti ed esigenze mutevoli costituisca oggi un aspetto imprescindibile. Un sistema complesso è definibile come un tutto che agisce ed evolve secondo una logica che non permette di ridurlo alla sommatoria delle singole parti. Questa definizione si adatta perfettamente al contesto urbano, composto da macro entità in perenne disequilibrio che si auto-organizzano e si sviluppano anche in base a un principio di antagonismo interno. Compito specifico della scienza della complessità è ricorrere a saperi multidisciplinari per vedere chiaro nel groviglio inestricabile di aspetti urbanistici, economici, sociologici, antropologici e filosofici alla base dell'evoluzione del sistema urbano complesso, non descrivibile in termini soltanto deterministici [Bertuglia, Vaio 2019, pp. 21-58]. L'ambito della ricerca ha adottato questo approccio ormai da alcuni anni ricercando integrazioni tra domini sempre più allargati, talvolta apparentemente distanti. In questo contesto, i sistemi informativi possono giocare un ruolo decisivo per migliorare conoscenza e monitoraggio nonché per una più efficace gestione sia del patrimonio costruito sia del territorio nel suo insieme [Riddhi, Siddhi, Hemal 2020]. La prospettiva prevede che prevenzione, gestione dell'emergenza, recupero e ricostruzione a seguito di eventi catastrofici [Shah et al. 2019] e rigenerazione urbana degli insediamenti siano pensati come azioni non distinte ma integrate tra loro [Empler 20।8, p. I]. II percorso è tracciato, tuttavia la didattica fatica ad applicare concretamente una visione di questo tipo. Tradizionalmente le discipline ingegneristiche vengono approfondite con insegnamenti di tipo verticale con limitata prospettiva di integrazione. Anche il Ministero dell'Ambiente si concentra sul ruolo che i giovani possono svolgere nel favorire maggiore adattamento promuovendo attività di sensibilizzazione, influenza sulle priorità politiche, sviluppo delle capacità, mobilitazione e creazione di imprese sociali [Ministero della Transizione Ecologica 202 I]. In concomitanza della revisione del piano degli studi di Ingegneria Edile del Politecnico di Torino, è stato messo a punto il nuovo insegnamento di Conoscenza del patrimonio costruito nell'epoca dei cambiamenti climatici del percorso Resilienza del costruito che declina l'orientamento della ricerca riscontrabile negli ultimi anni in un percorso didattico multidisciplinare. L'originalità del contributo crediamo sia individuabile nella circostanza di promuovere un terreno di confronto e di discussione allargata sul ruolo della didattica del disegno nell'ottica della Società 5.0, dove le tecnologie sono messe a servizio delle esigenze dell'uomo. (A.O).

\section{Sperimentazione didattica avanzata di un corso interdisciplinare}

Il tema di ricerca di carattere innovativo a cui l'insegnamento si riferisce è la strutturazione di un Digital Twin della città resiliente. L'approccio è orientato a fornire le più avanzate e consolidate metodologie e tecnologie per l'integrazione e l'interpretazione critica di dati eterogenei funzionali alla progettazione, gestione e conservazione, monitoraggio del patrimonio costruito a partire da un modello digitale multidimensionale della città. II punto di forza del corso risiede nella sua impostazione multidisciplinare che si traduce nell'interpretazione di una stessa entità a partire da punti di vista diversi e nella riconciliazione dei diversi risultati ottenuti. La sperimentazione didattica mette a sistema il contributo integrato (I8 CFU concentrati in un semestre) di quattro diversi insegnamenti (Geomatica, Modellazione digitale, Fisica Tecnica, ICT) che si completano a vicenda sia dal punto di vista dei riferimenti culturali e teorici delle tematiche trattate sia dell'esperienza applicativa. L'approccio educativo proposto è strutturato intorno alla definizione di un sistema di dati di input e di output che ruotano attorno al sistema di conoscenza del contesto urbanizzato. La metodologia adottata prevede le seguenti fasi: I) attività di brainstorming; 2) rilievo diretto e indiretto; 3) 
modellazione avanzata; 4) simulazione attività di monitoraggio e visualizzazione dati; 5) interpretazione critica del processo. II caso studio su cui è sperimentato l'approccio descritto è un distretto in via di riqualificazione di un tessuto urbano della cintura diTorino.

\section{Attività di brainstorming}

Allinizio del corso è proposto un momento di brainstorming al fine di stimolare un dibattito preliminare di discussione sulle tematiche di interesse e di identificare alcune parole chiave caratterizzanti il gemello digitale del sistema città. La medesima attività è riproposta alla fine del corso in fase di restituzione dei prodotti dell'esercitazione. Tale approccio consolida l'acquisizione da parte degli studenti dei contenuti del laboratorio. Le parole ricorrenti risultano trasversali tra gli insegnamenti e ne rafforzano la visione multidisciplinare.

\section{Rilievo diretto e indiretto}

Il rilievo si configura come attività preliminare per la formazione del quadro conoscitivo e contempla una filiera che fa convergere la ricerca bibliografica, storica e archivistica, con le attività sul campo di acquisizione delle informazioni sia tramite risorse umane sia strumentali. In particolare, sono utilizzate tecnologie di base che adottano un approccio moderno al rilievo tramite droni per l'acquisizione aerea del territorio. Le nuvole dense derivanti, relazionate con la rete di inquadramento mediante stazione totale, vengono elaborate per ottenere ortofoto, digital terrain model (DTM) e digital surface model (DSM) come prodotti finali. Questo approccio concorre allo scopo di estrarre informazioni geometriche strutturate.

\section{Modellazione avanzata}

La fase precedente genera dei dati che sono utilizzati come input per la modellazione digitale dell'area di studio (fig. I). Nella definizione di Digital Twin della città contribuiscono sicuramente una pluralità di rappresentazioni specifiche delle diverse scale di indagine, individuabili in modelli GIS e BIM. I prodotti derivanti dal rilievo strumentale sono utilizzati sia per impostare un sistema di riferimento GIS a scala urbana, sia per avviare procedure automatizzate Scan to BIM di conversione della scansione di punti in oggetti BIM a scala distrettuale ed edilizia tramite un approccio di reverse engineering. II calcolo della deviazione delle superfici modellate rispetto ai punti rilevati fornisce una chiave di lettura critica che consente di valutare la qualità e l'accuratezza del processo di sintesi. La modellazione avanzata deve consentire di gestire la complessità (LoG - Level of Geometry), l'accuratezza (LoR - Level of Reliability) e la risoluzione delle informazioni (Lol - Level of Information) alle diverse scale di indagine.

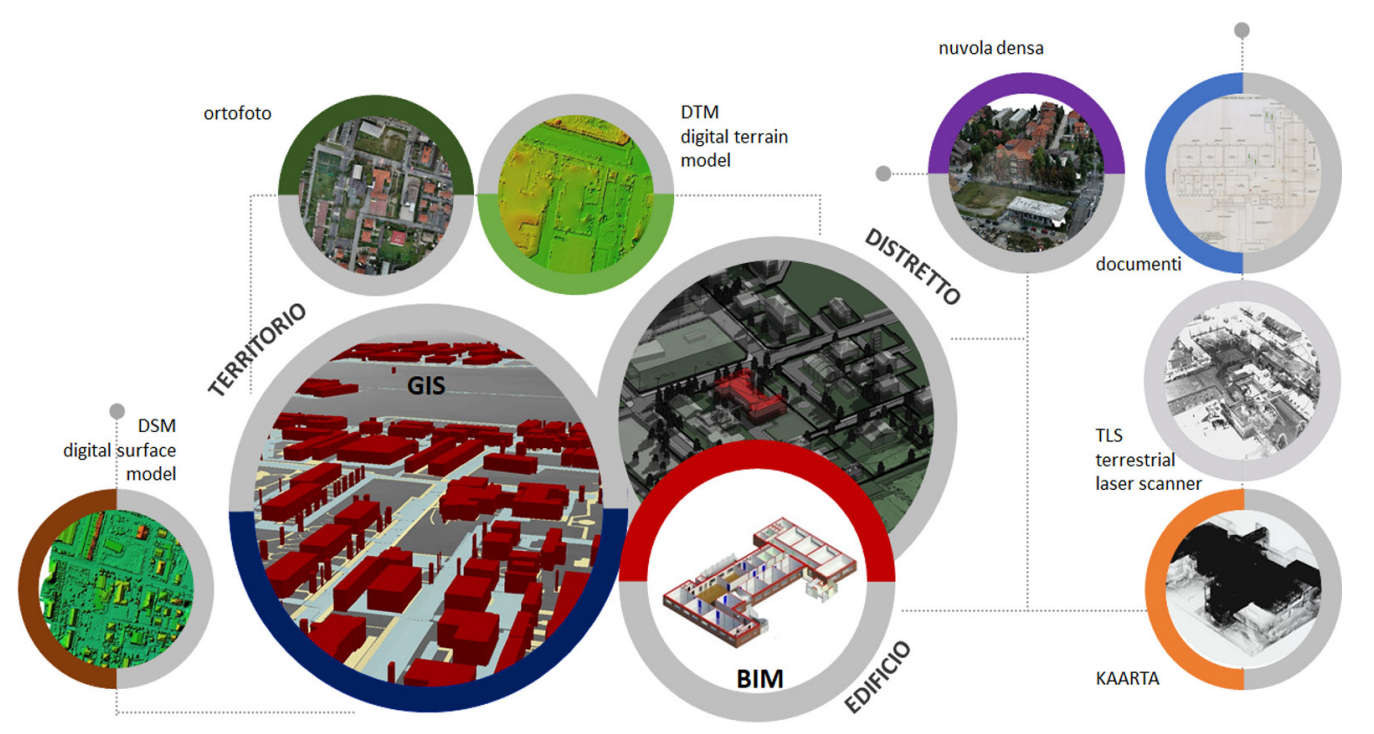


L'aspetto più interessante si riferisce alla componente informativa con l'analisi dei parametri richiesti per la conoscenza sistemica del patrimonio e della modalità più opportuna per rappresentarli. II modello BIM è concepito come collettore dei dati statici e dinamici caratteristici dell'edificio, utili per la valutazione di simulazioni specialistiche e di indicatori prestazionali per la configurazione di possibili scenari di intervento. Nello specifico, il modello si presta alla caratterizzazione termo-energetica dei componenti dell'involucro opachi, trasparenti e dei ponti termici organizzando in modo strutturato i dati per il calcolo. La disciplina della fisica tecnica aiuta la comprensione dell'effetto che gli eventi climatici hanno sull'edificio e sulla città e i parametri che entrano in gioco. II modello digitale dell'edificio aiuta a comprendere meglio anche i dati metereologici urbani e i fenomeni delle isole di calore, in quanto forniscono la rappresentazione delle ombre portate degli edifici che si ombreggiano l'uno con l'altro, delle sorgenti di calore interne alla città ovvero degli impianti di riscaldamento degli edifici, delle industrie presenti sul territorio o del traffico e di controllare la presenza di vegetazione nelle aree urbane. La definizione di archetipi per le tipologie edilizie aggiunge un livello informativo alla scala urbana e territoriale. La risoluzione di problemi complessi è attuabile tramite decomposizione e definizione di specifici algoritmi. L'approccio computazionale è utilizzato in ambiente BIM tramite linguaggio di programmazione visuale, ovvero un editor di algoritmi grafici accessibili, per democratizzare i dati, facilitare la compilazione e la manipolazione dei parametri geometrici e informativi. In questo contesto, un software come Autodesk Revit, tramite le Revit Application Program Interface (API), rende disponibili gli elementi del modello a programmi e servizi esterni. Inoltre, l'utilizzo dei nodi principali di Dynamo in combinazione con quelli personalizzati di Revit, consente allo studente di espandere in modo sostanziale i workflow parametrici per l'interoperabilità, la documentazione, l'analisi e la generazione. In questo modo il modello può essere integrato con altri domini di dati, come illustrato nel seguito.

Simulazione attività di monitoraggio e visualizzazione dati

Grazie alle moderne tecnologie dell'Information and Communication Technology (ICT), gli edifici, in tutte le fasi del loro ciclo di vita, dalla costruzione alla demolizione, possono essere monitorati in modo capillare con l'obiettivo di sviluppare politiche di controllo più intelligenti e intervenire su aspetti gestionali e di prevenzione. L'informatica svolge quindi un ruolo cardine nella gestione moderna delle città e restituisce un patrimonio informativo interessantissimo per gli ingegneri e gli architetti che ne studiano il comportamento. Si intrecciano le discipline, aumentano gli attori del processo, ma il fulcro del problema è sempre lo stesso: stabilire procedure e modalità per comunicare, scambiare, rendere interpretabili e visualizzabili i dati che si vogliono analizzare. II concetto di interoperabilità risulta valido anche in

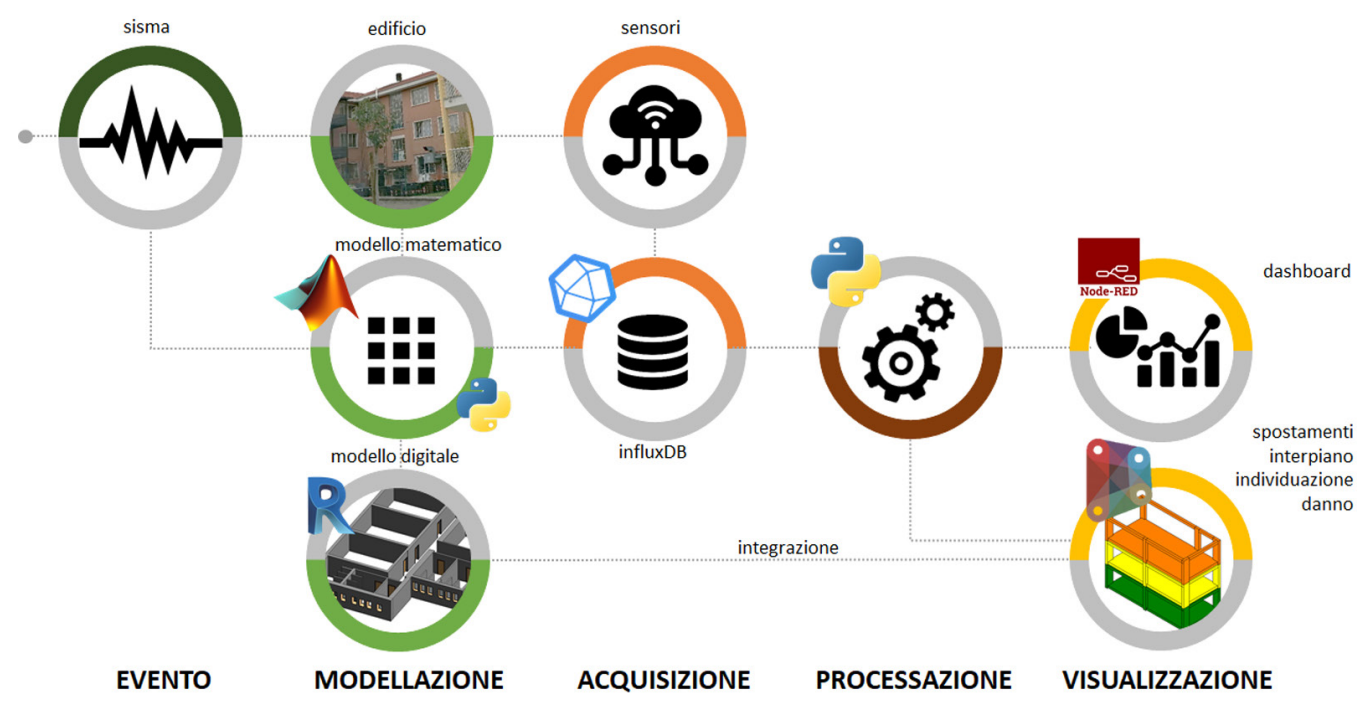


questo contesto, dove paradigmi di comunicazione REST, i più moderni che seguono un approccio publish/subscribe, stabiliscono un linguaggio comune. L'obiettivo è realizzare una attività di monitoraggio sismico riproducendo dei segnali di spostamento ai piani per il calcolo degli spostamenti interpiano (fig. 2). Questi dati, che misurerebbero i sensori reali in campo, vengono simulati tramite un modello matematico Matlab che riproduce il comportamento di un oscillatore a più gradi di libertà. Nell'ambito dell'esercitazione, il linguaggio Python
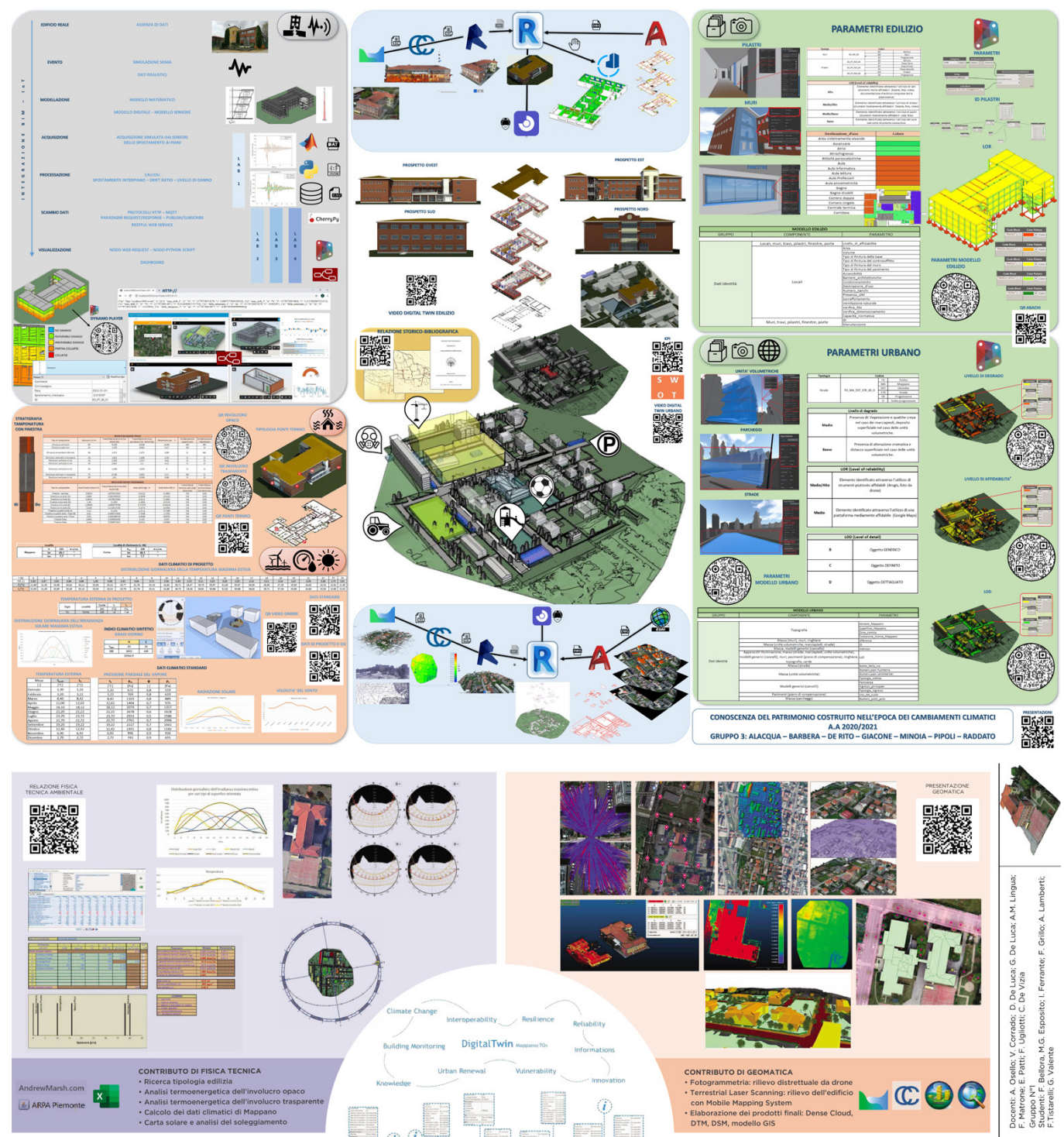

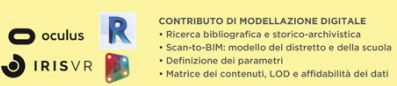
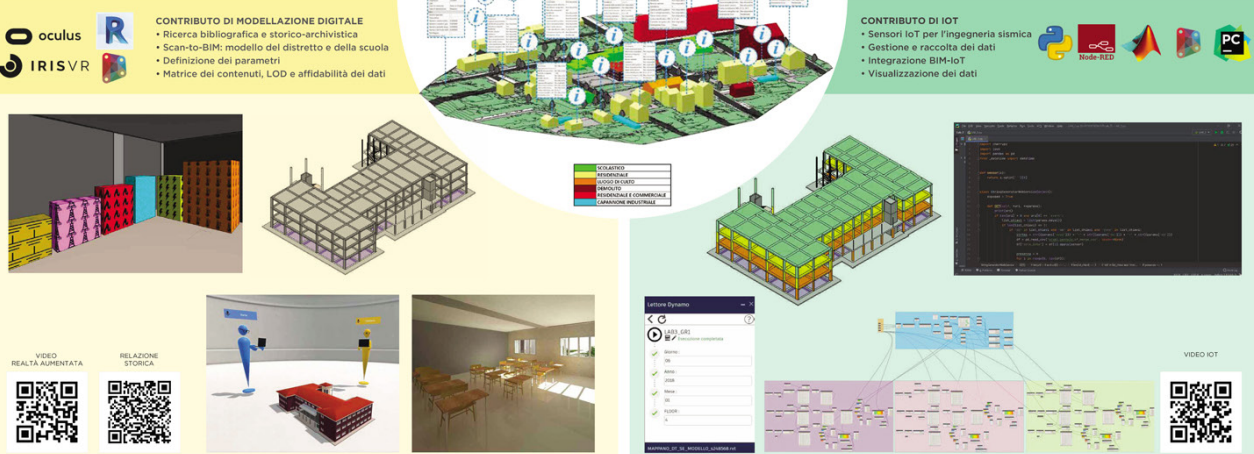

=

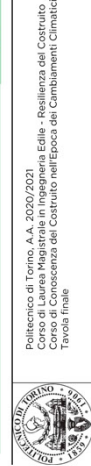


è utilizzato per sviluppare un sistema complesso distribuito che riceve dati dai sensori, li processa e li correla tra loro per sviluppare una applicazione di servizi mirata alla gestione dell'edificio e alimenta semplici dashboard di visualizzazione e modelli BIM. II massimo drift ratio è calcolato per valutare il livello di danno corrispondente all'evento sismico. L'integrazione BIM-loT è sperimentata tramite il linguaggio di programmazione visuale per rendere consultabili le informazioni dinamiche provenienti dai sensori all'interno del modello digitale e rappresentare graficamente il livello di danno provocato.

Interpretazione critica del processo

La comunicazione dei risultati di gruppo prodotti nell'ambito dell'esercitazione pratica è organizzata tramite l'esposizione di una tavola di sintesi, che costringe lo studente ad attuare una interpretazione critica di quanto elaborato, mettendo in luce gli aspetti più significativi di ogni SSD coinvolto. Dall'analisi delle tavole (fig. 3) emerge chiaramente l'approccio integrale e integrato che il corso si propone con forza di trasmettere. Ė richiesta la predisposizione di una analisi SWOT al fine di stimolare una valutazione del percorso di conoscenza intrapreso, evidenziandone, quindi, non solo gli aspetti favorevoli ma anche le difficoltà. L'arricchimento maggiore dello studente, è infatti riscontrabile nella formulazione di un metodo di lavoro che lo abitua ad approcciare dei problemi complessi, che comportano, quindi, aspetti sfidanti e criticità da superare per raggiungere l'obiettivo. L'attuale situazione pandemica e la didattica a distanza hanno permesso inoltre di sperimentare una nuova modalità di interazione studente-docente per la revisione dei modelli digitali tramite esperienze con i visori di realtà virtuale (fig. 4) [Ugliotti et al. 202 I]. L'immersione nei gemelli digitali implementati ha portato a una maggiore consapevolezza delle aree e del possibile utilizzo di questo tipo di strumenti in ottica conoscitiva e gestionale. (FM.U.).

\section{Conclusioni}

La sinergia dei contributi disciplinari affrontati tramite il corso sperimentale di didattica avanzata ha portato alla definizione di un insegnamento integrato complesso che ha conseguito risultati di gran lunga superiori alla sommatoria di quelli raggiungibili tramite corsi distinti specialistici. L'ulteriore sfida (ancora in corso), riguarda il coinvolgimento di tutti gli insegnamenti del primo anno della LM a confrontarsi con lo stesso caso studio per contribuire, ciascuno con le proprie competenze specifiche, ad arricchire i contenuti del Digital Twin, e per utilizzare le informazioni in esso contenute per proporre soluzioni di tipo progettuale,

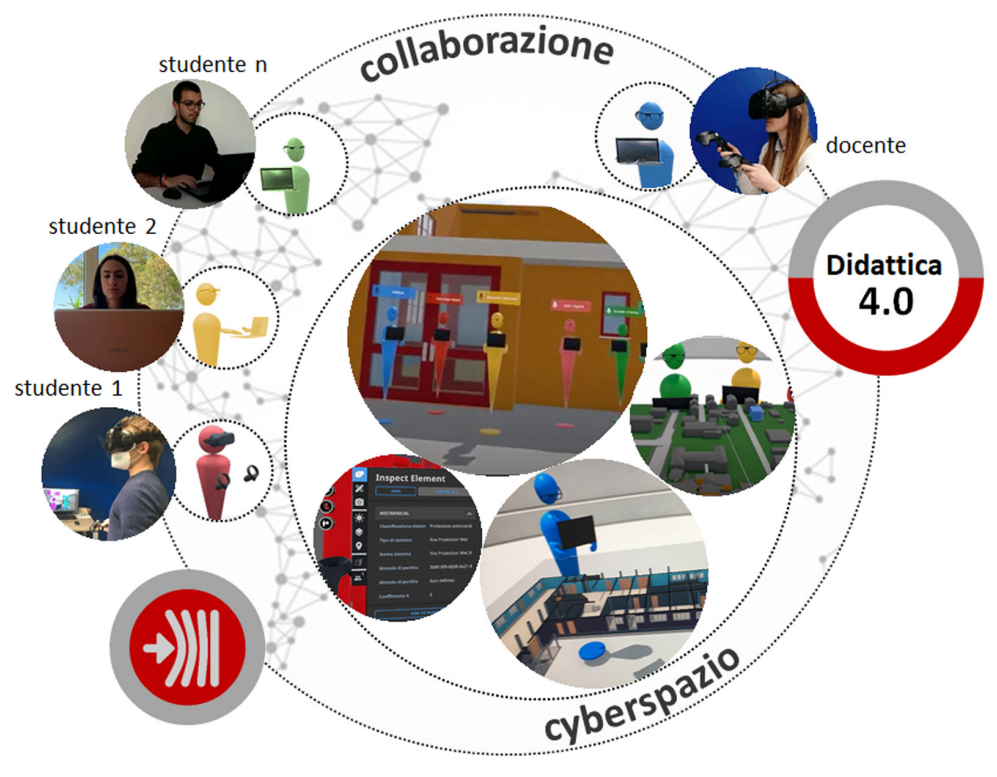


nel rispetto del contesto urbano indagato al fine di incrementarne la sua resilienza dal punto di vista storico, architettonico, strutturale, economico, sociale, ecc. Al termine dell'anno accademico gli studenti dovranno redigere una tavola di sintesi critica dei contributi dei singoli insegnamenti e delle interconnessioni a giustificazione delle scelte progettuali messe in atto. II risultato sarà fonte di una mostra e di un confronto pubblico con gli stakeholder del territorio con i quali il percorso degli studi è stato condiviso nei contenuti in fase di progettazione.

Tra le considerazioni più interessanti emerse da parte degli studenti durante la presentazione dei loro risultati dell'esercitazione del corso, emerge il concetto di Digital Twin Empatico. L'idea nasce dall'analisi di come una progettazione attenta derivante da scelte intelligenti possa garantire il benessere della società. L'uomo è, infatti, il 'sensore' più importante per la città, tanto sensibile quanto complesso da interpretare. La metodologia esposta può ulteriormente essere arricchita, sia in termini di dati collezionabili sia di figure professionali coinvolte, attraverso la mappatura di indicatori che rappresentano aspetti di tipo socio-psicologico. Serendipity può essere uno dei parametri che esprimono il riscontro soggettivo dei cittadini e degli occupanti degli edifici in relazione al gradimento dei luoghi, del comfort, dello stato di rilassamento e della percezione di benessere che questi trasmettono. La correlazione di queste informazioni immateriali che si evolvono dinamicamente nel tempo con il gemello digitale della città abilita analisi socio-culturali rappresentative del rapporto uomo/ ambiente [White, Zink, Codecá, Clarke 202I]. In quest'ottica, la resilienza del patrimonio costruito genera una resilienza socio-culturale e, di conseguenza, processi virtuosi e collaborativi preziosi per la sostenibilità delle città del futuro. (A.O.).

\section{Ringraziamenti}

Gli autori ringraziano i docenti e gli studenti del corso di laurea magistrale di Conoscenza del patrimonio costruito nell'era dei cambiamenti climatici A.A. 2020/202I che hanno contribuito alla sperimentazione dell'approccio didattico illustrato nel presente articolo.

II contributo è frutto del lavoro congiunto degli autori. La cura delle singole parti è stata ripartita come indicato in ciascun paragrafo (F.M.U. e A.O.).

\section{Riferimenti bibliografici}

Bertuglia C., Vaio F. (2019). Il fenomeno urbano e la complessità. Torino: Bollati Boringhieri editore.

Empler T. (20 I 8). Procedura di Information Modelling per rappresentare un territorio colpito dal sisma. In disègno, 2/20 I 8, pp. $147-156$.

Ministero della Transizione Ecologica (202l) <https://www.minambiente.it/> (consultato il 3 marzo 202l).

Riddhi D., Siddhi D., Hemal T. (2020). Digital Twins: Current problems in Smart City and Recommendations for future technology. In: International Research Journal of Engineering and Technology (IRJET), 07, Issue: 05.< https://www.irjet.net/archives/V7/ i5/IRJET-V7I5620.pdf> (consultato il 20 gennaio 202I).

Shah S.A. et al. (2019). Towards Disaster Resilient Smart Cities: Can Internet of Things and Big Data Analytics Be the Game Changers?. In: IEEE Access, 7. < https://www.researchgate.net/publication/334408 I 58_Towards_Disaster_Resilient_Smart_Cities_Can_Internet_of_Things_and_Big_Data_Analytics_Be_the_Game_Changers> (consultato il 23 gennaio 2021 ).

Ugliotti F. M. (in corso di stampa). EEB Project system integration and technology sperimentation matrix. In M. Del Giudice, A. Osello (a cura di). Handbook of Research on Developing Smart Cities Based on Digital Twins. USA: IGI Global.

Ugliotti F. M. et al. (in corso di stampa). Students and teachers turn into avatars for online education. INTED202 I Proceedings. Valencia, 8-9/03/2021.Valencia: IATED Academy.

White G. et al. (202 I). A digital twin smart city for citizen feedback. In Cities, n. I I 0. <https://www.researchgate.net/publication/34838280 I_A_digital_twin_smart_city_for_citizen_feedback > (consultato il 22 febbraio 202I).

\section{Autori}

Francesca Maria Ugliotti, Politecnico di Torino, francesca.ugliotti@polito.it

Anna Osello, Politecnico di Torino, anna.osello@polito.it

Per citare questo capitolo: Ugliotti Francesca Maria, Osello Anna (2021). II disegno riscopre la sua intrinseca resilienza multidisciplinare/ Drawing rediscovers its intrinsic multidisciplinary resilience. In Arena A., Arena M., Mediati D., Raffa P. (a cura di). Connettere. Un disegno per annodare e tessere. Linguaggi Distanze Tecnologie. Atti del $42^{\circ}$ Convegno Internazionale dei Docenti delle Discipline della Rappresentazione/Connecting. Drawing for weaving relationship. Languages Distances Technologies. Proceedings of the $42^{\text {th }}$ International Conference of Representation Disciplines Teachers. Milano: FrancoAngeli, pp. $1228-124 \mid$. 


\section{Drawing Rediscovers its Intrinsic Multidisciplinary Resilience}

Francesca Maria Ugliotti Anna Osello

\section{Abstract}

Multidisciplinarity, interoperability and resilience are the challenges that the drawing discipline faces in the context of the fourth industrial revolution. The real innovation lies in the definition of digital representation procedures and tools that support the interpretation of increasingly complex information. The inexhaustible expressive language of drawing acquires renewed vigour from the Digital Twin paradigm to explore increasingly high-performance forms of representation of the built heritage. This impulse must be strongly affirmed in university courses as well, in order to train engineers and architects capable of dealing with the changing needs of the modern world. The article illustrates an innovative didactic approach, developed from a previous research activity, which recognises in drawing the transversal capacity to connect knowledge, techniques and tools.

Keywords

drawing, interdisciplinarity, interoperability, didactics, Digital Twin.

Innovative multidiscipli-
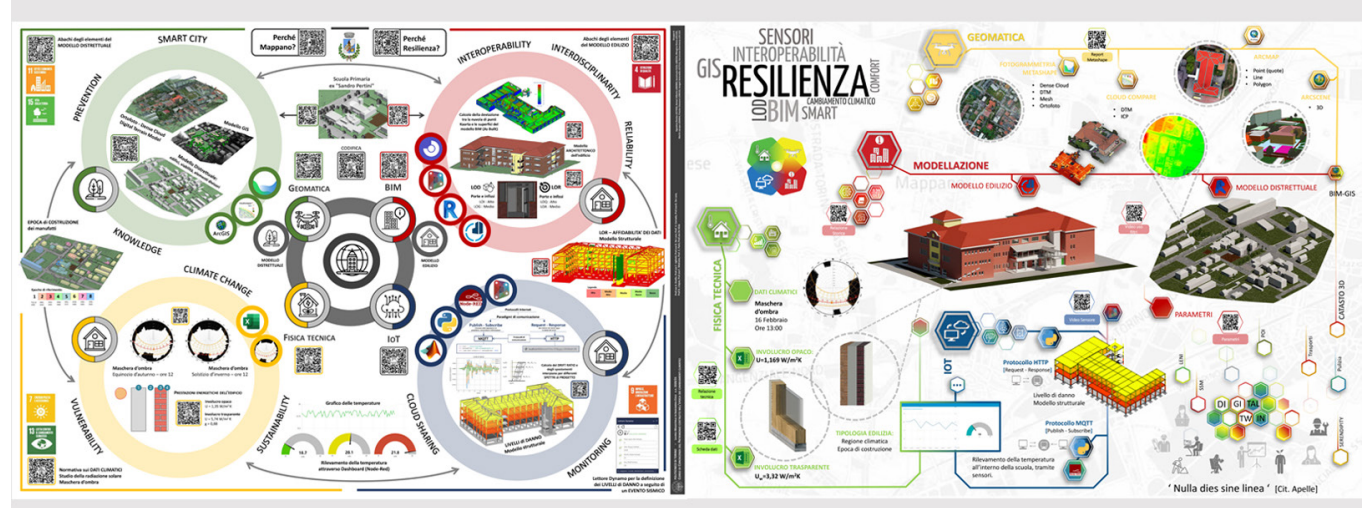
Introduction

Resilience and adaptation to climate change are the topics at the centre of interest to which increasingly concrete and feasible responses will have to be given in the coming years. In this scenario, cities and buildings play a crucial role, making it necessary to rethink the realities in which we live and how they are analysed and represented. The current pandemic period has underlined how adapting to changing contexts and needs is now an essential aspect. A complex system can be defined as a whole that acts and evolves according to a logic that does not allow it to be reduced to the sum of its individual parts. This definition is perfectly suited to the urban context, composed of macro-entities in perpetual disequilibrium that organize themselves and develop based on internal antagonism. The specific task of complexity science is to make use of multidisciplinary knowledge in order to see clearly into the inextricable tangle of urban, economic, sociological, anthropological and philosophical aspects underlying the evolution of the complex urban system, which cannot be described in deterministic terms only [Bertuglia, Vaio 2019, pp. 21-58]. The research field has been adopting this approach for some years now, seeking integrations between increasingly enlarged, sometimes apparently distant, domains. In this context, information systems can play a decisive role in improving knowledge and monitoring and more effective management of both the built heritage and the territory [Riddhi, Siddhi, Hemal 2020]. The perspective envisages that prevention, emergency management, recovery and reconstruction following catastrophic events [Shah et al. 2019] and urban regeneration of settlements are thought of as actions that are not distinct but integrated [Empler 20।8, p. I]. The path is mapped out, yet didactics struggle to apply such a vision concretely. Traditionally, engineering disciplines are deepened with vertical type teachings with a limited perspective of integration. The Ministry of Environment also focuses on the role that young people can play in fostering greater adaptation by promoting awareness-raising activities, influencing policy priorities, capacity building, mobilization, and creating social enterprises [Ministero della Transizione Ecologica, 202 I]. As part of the revision of the programme of studies for Building Engineering at the Politecnico di Torino, the new course Conoscenza del patrimonio costruito nell'epoca dei cambiamenti climatici has been developed, reflecting the research orientation found in recent years in a multi-disciplinary course of study. We believe that this contribution's originality lies in the fact that it promotes a ground for comparison and broad discussion on the role of design education in the context of Society 5.0, where technologies are put at the service of human needs. (A.O).

\section{Advanced didactic experimentation of an interdisciplinary course}

The innovative research theme to which the course refers is the structuring of a resilient city's Digital Twin. The approach is oriented to provide the most advanced and consolidated methodologies and technologies for integrating and critical interpretation of heterogeneous data functional to the design, management and conservation, monitoring of the built heritage starting from a multi-dimensional digital model of the city. The course's strength lies in its multidisciplinary approach, which translates into the interpretation of the same entity from different points of view and the reconciliation of the different results obtained. The didactic experimentation brings together the integrated contribution ( I 8 CFU concentrated in one semester) of four different courses (Geomatics, Digital Modelling, Technical Physics, ICT), which complement each other both from the point of view of the cultural and theoretical references of the topics dealt with and of the application experience. The proposed educational approach is structured around defining a system of input and output data that revolve around the knowledge system of the urbanised context. The methodology adopted includes the following phases I) brainstorming activities; 2) direct and indirect survey; 3) advanced modelling; 4) simulation monitoring activities and data visualisation; 5) critical interpretation of the process. The case study on which the described approach is tested is a district that is part of an urban fabric undergoing redevelopment in the Turin belt. 


\section{Brainstorming activities}

At the beginning of the course, a brainstorming session is proposed to stimulate a preliminary discussion on the topics of interest and identify some keywords characterizing the city system's Digital Twin. The same activity is repeated at the end of the course when the exercise products are returned. This approach consolidates the students' acquisition of the laboratory contents. The recurring words are transversal between the subjects and reinforce the multidisciplinary vision.

\section{Direct and indirect survey}

The survey is configured as a preliminary activity for creating the cognitive framework and contemplates a chain that brings together bibliographic, historical and archival research with field activities to acquire information both through human and instrumental resources. In particular, basic technologies adopt a modern approach to surveying using drones for the aerial acquisition of the territory. The resulting dense clouds, related to the framing network employing a total station, are processed to obtain orthophotos, digital terrain models (DTM) and digital surface models (DSM) as final products. This approach contributes to the goal of extracting structured geometric information.

\section{Advanced modelling}

The previous phase generates data that is used as input for the digital modelling of the study area (fig. I). In the definition of the Digital Twin of the city, a plurality of specific representations of the different scales of investigation, identifiable in GIS and BIM models, certainly contribute. The products deriving from the instrumental survey are used both to set up a GIS reference system at the urban scale and to start automated Scan to BIM procedures of conversion of point scans into BIM objects at district and building scale through a reverse engineering approach. The calculation of the deviation of the modelled surfaces from the scanned points provides a critical key to evaluating the synthesis process's quality and accuracy. Advanced modelling has to manage complexity (LoG - Level of Geometry), accuracy (LoR - Level of Reliability) and resolution of information (Lol - Level of Information) at different scales of investigation.

The most interesting aspect refers to the information component with the analysis of the parameters required for the heritage's systemic knowledge and the most appropriate way to represent them. The BIM model is conceived as a collector of static and dynamic data characteristic of the building, useful for evaluating specialized simulations and performance indicators for the configuration of possible intervention scenarios. Specifically, the model

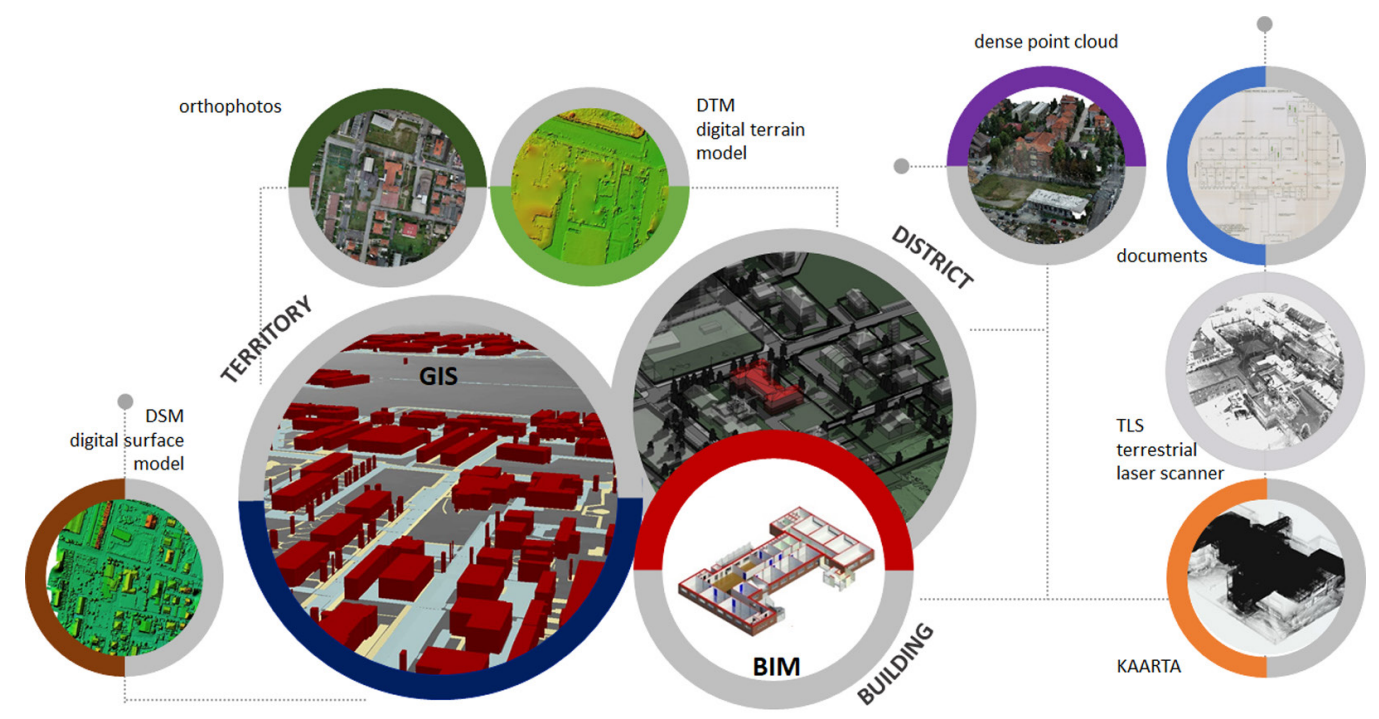


provides the thermal-energy characterisation of opaque and transparent envelope components and thermal bridges by organising the data for calculation in a structured way. The discipline of technical physics helps understand the effect that climatic events have on the building and the city and the parameters that come into play. The digital building model also helps better to understand urban meteorological data and heat island phenomena, as it provides a representation of the shadows cast by buildings shading each other, heat sources within the city, i.e. building heating systems, industries in the area or traffic, and to control the presence of vegetation in urban areas. The definition of archetypes for building types adds an informative layer at the urban and spatial scale. Complex problems can be solved by decomposition and the definition of specific algorithms. The computational approach is used in the BIM environment through a visual programming language, i.e. an editor of accessible graphic algorithms, to democratise data, facilitate the compilation and manipulation of geometric and informative parameters. In this context, software such as Autodesk Revit makes model elements available to external programs and services via Revit Application Program Interfaces (APIs). Besides, the use of Dynamo core nodes combined with Revit custom nodes allows the student to substantially expand parametric workflows for interoperability, documentation, analysis, and generation. In this way, the model can be integrated with other data domains, as illustrated below.

Simulation monitoring activities and data visualisation

Thanks to modern Information and Communication Technology (ICT), buildings at all stages of their life cycle, from construction to demolition, can be extensively monitored to develop more intelligent control policies and intervene in management and prevention aspects. Information technology, therefore, plays a pivotal role in the modern management of cities and provides a wealth of information that is of great interest to engineers and architects studying their behaviour. The disciplines intertwine, the number of players in the process increases. However, the core of the problem is always the same: establishing procedures and methods for communicating, exchanging, making interpretable and visualisable the data to be analysed. The interoperability concept is also valid in this context, where REST communication paradigms, the most modern of which follow a publish/subscribe approach, establish a common language. The objective is to carry out a seismic monitoring activity by reproducing displacement signals at floors to calculate inter-storey drift (fig. 2). This data, which would measure real sensors in the field, is simulated using a Matlab mathematical model that reproduces a multi-degree-of-freedom oscillator's behaviour. As part of the exercise, the Python language is used to develop a complex distributed system that receives data from the sensors and processes and correlates it to develop a service application aimed

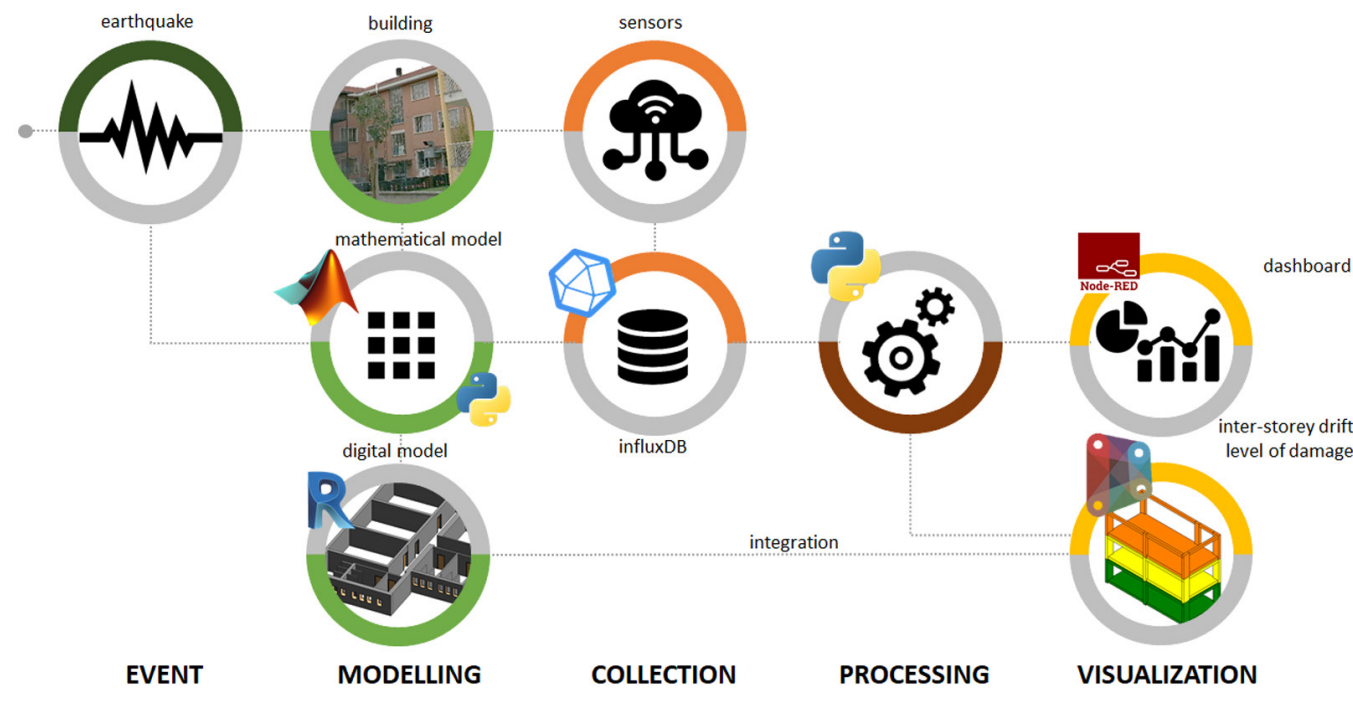


at building management and feeding simple visualisation dashboards and BIM models. The maximum drift ratio is calculated to assess the level of damage corresponding to the seismic event. The BIM-loT integration is tested through the visual programming language to make the dynamic information coming from the sensors available within the digital model, and graphically represent the level of damage caused.
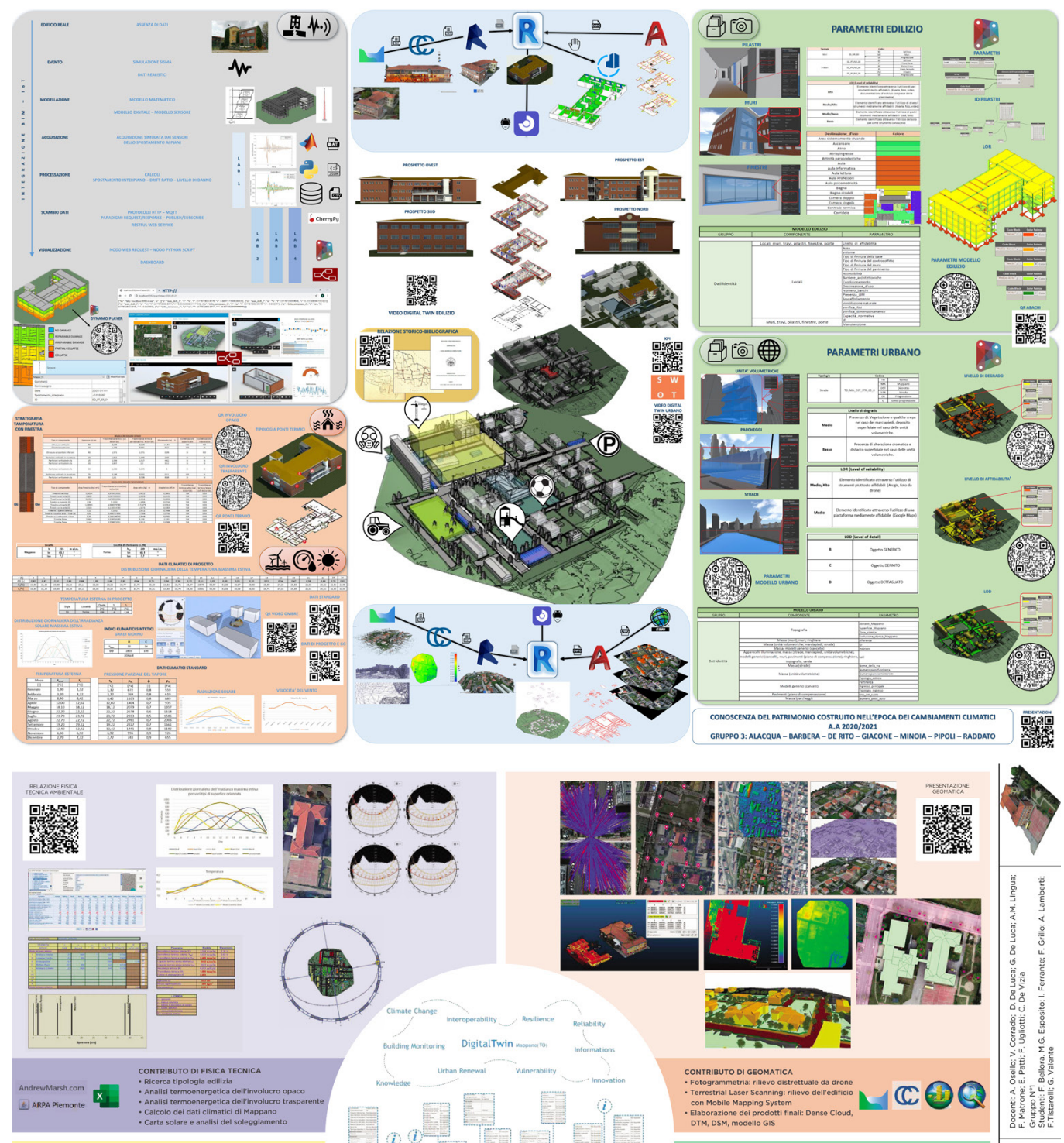

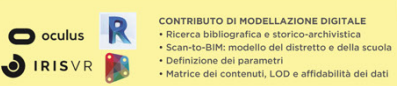
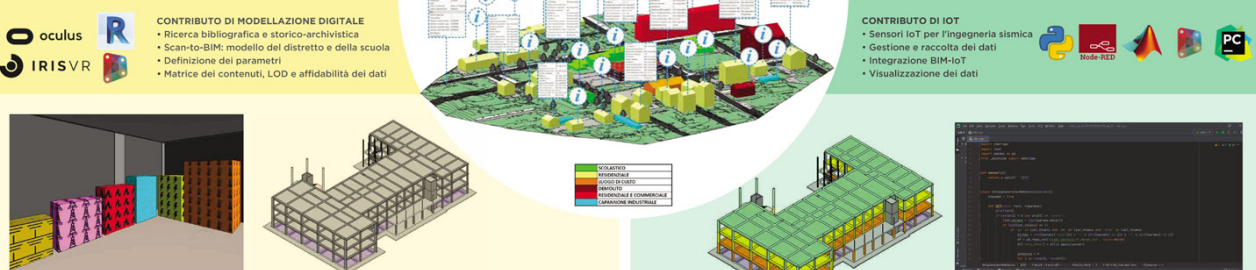

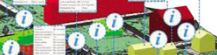

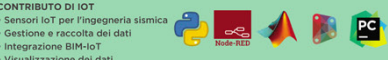

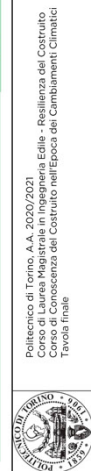


Critical interpretation of the process

The communication of the group results produced during the practical exercise is organised by presenting a summary table, which forces the student to carry out a critical interpretation of what has been elaborated, highlighting the most significant aspects of each SSD involved. The boards' analysis (fig. 3) clearly shows the integral and integrated approach that the course aims to convey. The preparation of a SWOT analysis is required to stimulate an evaluation of the knowledge pathway undertaken, thus highlighting the favourable aspects and the difficulties. The greatest enrichment of the student, in fact, is found in the formulation of a working method that accustoms him to approaching complex problems, which therefore involve challenging aspects and critical issues to be overcome in order to achieve the objective. The current pandemic and distance learning have also made it possible to experiment with a new mode of student-teacher interaction for reviewing digital models through experiences with virtual reality viewers (fig. 4) [Ugliotti et al. 202 I]. Immersion in the Digital Twins implemented has led to a greater awareness of the areas and possible use of this type of tool from a cognitive and management perspective. (F.M.U.).

\section{Conclusions}

The synergy of the disciplinary contributions addressed through the experimental advanced didactics course has led to the definition of a complex integrated course that has achieved results far superior to those achievable through separate specialist courses. A further challenge (still in progress) concerns the involvement of all the subjects of the first year of the LM in confronting the same case study in order to contribute, each with their own specific skills, to enrich the contents of the Digital Twin and to use the information contained therein to propose design solutions, respecting the urban context investigated in order to increase its resilience from the historical, architectural, structural, economic, social, etc. point of view. At the end of the academic year, students will have to draw up a critical synthesis board of the individual courses' contributions and the interconnections to justify the design choices made. The result will be the source of an exhibition and of a public discussion with the stakeholders of the territory with whom the course of studies has been shared in its contents during the planning phase. Among the most interesting considerations that emerged from the students during the presentation of their course results, exercise is the Empathetic Digital Twin concept. The idea comes from the analysis of how careful design resulting from intelligent choices can guarantee society's well-being. Human beings are, in fact, the most

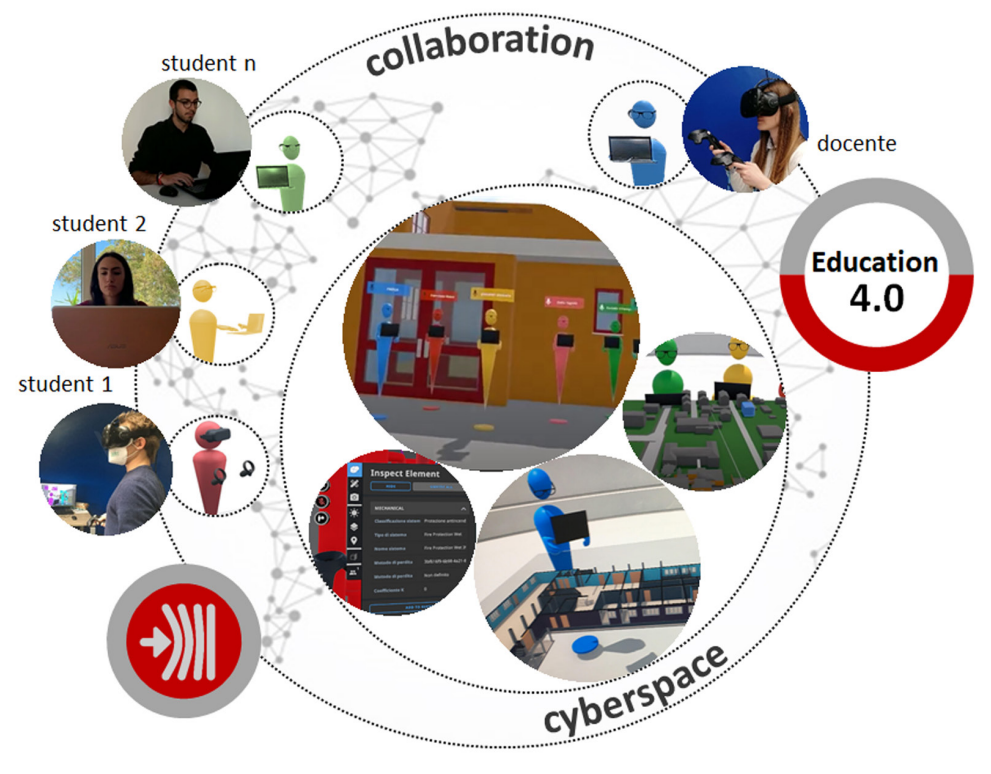


important 'sensor' for the city, as sensitive as they are complex to understand. The methodology outlined above can be further enriched, both in terms of collectable data and the professional figures involved, by mapping indicators representing socio-psychological aspects. Serendipity can be one of the parameters that express citizens' subjective feedback and occupants of buildings concerning the enjoyment of places, comfort, state of relaxation, and perception of well-being that they convey. The correlation of this intangible information that evolves dynamically over time with the city's Digital Twin enables representative socio-cultural analyses of the human-environment relationship. In this perspective, the built heritage's resilience generates socio-cultural resilience and, consequently, virtuous and collaborative processes that are valuable for the sustainability of future cities. (A.O.).

\section{Acknowledgements}

The authors would like to thank the teachers and students of the master's degree course Conoscenza del patrimonio costruito nell'epoca dei cambiamenti climatici A.Y. 2020/2021, who contributed to the teaching approach's testing illustrated in this article. The contribution is the result of joint work by the authors. The individual parts' editing has been divided, as indicated in each paragraph (F.M.U. and A.O.).

\section{References}

Bertuglia C., Vaio F. (2019). Il fenomeno urbano e la complessità. Torino: Bollati Boringhieri editore.

Empler T. (20 I 8). Procedura di Information Modelling per rappresentare un territorio colpito dal sisma. In disègno, 2/20 I 8, pp. $147-156$.

Ministero della Transizione Ecologica (202I) <https://www.minambiente.it/> (accessed 202I, March 3).

Riddhi D., Siddhi D., Hemal T. (2020). Digital Twins: Current problems in Smart City and Recommendations for future technology. In: International Research Journal of Engineering and Technology (IRJET), 07, Issue: 05.< https://www.irjet.net/archives/V7/ i5/IRJET-V7I5620.pdf> (accessed 202I, January 23).

Shah S.A. et al. (2019). Towards Disaster Resilient Smart Cities: Can Internet ofThings and Big Data Analytics Be the Game Changers?. In: IEEE Access, 7. <https://www.researchgate.net/publication/334408I58_Towards_Disaster_Resilient_Smart_Cities_Can_Internet_of_Things_and_Big_Data_Analytics_Be_the_Game_Changers> (accessed 202 I, January 23).

Ugliotti F. M. (in corso di stampa). EEB Project system integration and technology sperimentation matrix. In M. Del Giudice, A. Osello (a cura di). Handbook of Research on Developing Smart Cities Based on Digital Twins. USA: IGI Global.

Ugliotti F. M. et al. (in corso di stampa). Students and teachers turn into avatars for online education. INTED202I Proceedings. Valencia, 8-9/03/2021. Valencia: IATED Academy.

White G. et al. (202 I). A digital twin smart city for citizen feedback. In Cities, n. I I 0. <https://www.researchgate.net/publication/34838280 I_A_digital_twin_smart_city_for_citizen_feedback $>$ (accessed 202 I, February 22).

\section{Authors}

Francesca Maria Ugliotti, Politecnico di Torino, francesca.ugliotti@polito.it Anna Osello, Politecnico di Torino, anna.osello@polito.it

To cite this chapter. Ugliotti Francesca Maria, Osello Anna (2021). Il disegno riscopre la sua intrinseca resilienza multidisciplinare/ Drawing rediscovers its intrinsic multidisciplinary resilience. In Arena A., Arena M., Mediati D., Raffa P. (a cura di). Connettere. Un disegno per annodare e tessere. Linguaggi Distanze Tecnologie. Atti del $42^{\circ}$ Convegno Internazionale dei Docenti delle Discipline della Rappresentazione/Connecting. Drawing for weaving relationship. Languages Distances Technologies. Proceedings of the $42^{\text {th }}$ International Conference of Representation Disciplines Teachers. Milano: FrancoAngeli, pp. $1228-124 \mid$. 